\title{
An Alternative Method for the Synthesis of S-Methylmethanethiosulfonate
}

\author{
Arif Ali Khan* \\ University School of Basic \& Applied Sciences, Guru Gobind Singh Indraprastha University, India
}

Submission: April 23, 2018; Published: April 26, 2018

"Corresponding author: Arif Ali Khan, University School of Basic \& Applied Sciences, Guru Gobind Singh Indraprastha University, Dwarka, Sector 16-C, New Delhi-110078, India, Tel: +91 98189 74597; Email: arif@ipu.edu

\begin{abstract}
DMSO is converted to S-Methylmethanethiosulfonate in good yields in the presence of catalytic amount of $\mathrm{TiCl}_{4}$. It provides the first example of conversion of DMSO to S-Methylmethanethiosulfonate catalysed / promoted by $\mathrm{TiCl}_{4}$. The product has been characterised by ${ }^{1} \mathrm{H}$ - and ${ }^{13} \mathrm{C}$-n.m.r. spectroscopy and mass spectrometry.
\end{abstract}

Keywords: DMSO; S-Methyl methanethiosulfonate; $\mathrm{TiCl}^{4}$

Abbreviations: DMSO : dimethyl sulfoxide

\section{Introduction}

DMSO and other sulfoxides are widely used in organic synthesis [1-4]. The presence of metal complexes in such reactions often results in oxidation of sulfoxides and sometime it results even in activation of Carbon-Sulfur bond of sulfoxides giving unexpected products which might lead to confusion [5]. In a similar way, a reaction of DMSO in presence of $\mathrm{TiCl}_{4}$ in 1,2-Dichloroethane resulted in the formation of S-Methylmethanethiosulfonate. S-Methylmethanethiosulfonate is a very useful sulfenylating reagent for organic synthesis as well as for biological applications [6-15]. Particularly, it is used for introduction of $\mathrm{SCH}_{3}$ groups in aromatic rings and other organic compounds including biologically active molecules. In general, thiosulfonic S-esters are stable and reactive species; however their use has been limited by the lack of easy and practical preparations. A number of methods are known for the preparation of S-Methylmethanethiosulfonate which involves harmful toxic reagents or typical lengthy work-up which distract the interest of chemists [16-24]. Herein, we report a novel and very simple method for the synthesis of the title compound.

\section{Results and Discussion}

Conversion of DMSO (1) to S-methylmethanethiosulfonate (2) is attained selectively at reflux conditions in 1,2-dichloroethane in presence of $\mathrm{TiCl}_{4}$ (Equation 1). The progress of the reactions is monitored by TLC and it takes 2-3 hrs for completion.

$$
2 \mathrm{Me}_{2} \mathrm{SO} \underset{\text { (1) }}{\stackrel{\mathrm{TiCl}_{4} \text {, Solvent }}{\longrightarrow}} \mathrm{MeSO}_{2} \mathrm{SMe}
$$

During usual work up of the reaction some brownish impurities are developed which can be easily removed by short path distillation under vacuum and as a result a neat colorless liquid (2) is obtained in $79 \%$ yield. The ${ }^{1} \mathrm{H}$ NMR of this compound shows two peaks as singlet at 2.71 and $3.32 \mathrm{ppm}$ corresponding to chemically two different methyl groups indicating that the two methyl groups are low field shifted compared to DMSO which shows a single peak at $2.62 \mathrm{ppm}$. Similarly, ${ }^{13} \mathrm{C}$ NMR spectrum of 2 shows two peaks at 18.2 and $48.8 \mathrm{ppm}$ corresponding to two different methyl groups and non-decoupled 13C-nmr spectrum further shows two methyl carbon as quartet indicating the presence of three coupling protons on each carbon atoms. The fragmentation pattern of 2 obtained by EI $(30 \mathrm{eV})$ shows major products corresponding to $126(\mathrm{M}+), 111\left(\mathrm{CH}_{3} \mathrm{SO}_{2} \mathrm{~S}+\right)$, $79\left(\mathrm{CH}_{3} \mathrm{SO}_{2}+\right), 63\left(\mathrm{CH}_{3} \mathrm{SO}+\right)$, and $47\left(\mathrm{CH}_{3} \mathrm{~S}+\right)$ respectively. The fragment $(\mathrm{M}=63)$ is also generated in thermolysis of DMSO due to loss of methyl radical from the molecular ion [25].

Attempts will be made to explore the potential of S-Methylmethanethiosulfonate towards various organophosphorus compounds.

\section{Experimental}

Caution: This sulfenate should be handled carefully as it possesses a pungent smell and may cause vomiting and headache).

Synthesis of Compound (2): A mixture of DMSO (23.4 g, $0.30 \mathrm{~mol})$ and $\mathrm{TiCl}_{4}(0.190 \mathrm{~g}, 0.009 \mathrm{~mol})$ in $100 \mathrm{~mL}$ of freshly 
distilled 1,2-dichloroethane was heated at reflux for 2-3 $\mathrm{h}$. After completion of the reaction (marked by a single spot of S-methylmethanethiosulfonate on TLC), the reaction mixture was cooled to room temperature and then washed with water. The 1,2-dichloroethane solution was dried (anhydrous $\mathrm{Na}_{2} \mathrm{SO}_{4}$ ) and evaporated on a rotary evaporator to give a light brown liquid which became dark on exposure to air. This product 2 was distilled by short path distillation under vacuum (13.60 g, 70.6\%; b.pt. $80-82{ }^{\circ} \mathrm{C} / 0.05 \mathrm{mmHg}$ ) as a neat colorless liquid. Calcd. Anal.: C, 19.03; H, 4.79; Found: C, 18.99; H, 4.78. ${ }^{1} \mathrm{H}$ NMR(300 $\left.\mathrm{MHz}, \mathrm{CDCl}_{3}\right)$ 2.71(s,3H), 3.32(s,3H); ${ }^{13} \mathrm{C} \mathrm{NMR}\left(75 \mathrm{MHz}, \mathrm{CDCl}_{3}\right) 18.2$, 48.8; MS (EI, $30 \mathrm{eV}) \mathrm{m} / \mathrm{z}=126(62 \%, \mathrm{M}+), 111\left(10 \%, \mathrm{CH}_{3} \mathrm{SO}_{2} \mathrm{~S}+\right)$, $79\left(60 \%, \mathrm{CH}_{3} \mathrm{SO}_{2}+\right) 63\left(61 \%, \mathrm{CH}_{3} \mathrm{SO}+\right), 47\left(100 \%, \mathrm{CH}_{3} \mathrm{~S}+\right)$.

(P.S.: 1,2-Dichloroethane was used as freshly distilled. DMSO and $\mathrm{TiCl}_{4}$ were used as received).

\section{Acknowledgement}

Author is thankful to CSIR-New Delhi for financial assistance.

\section{References}

1. GH Posner (1988) The Chemistry of Sulfones and Sulfoxides. Wiley, New York, USA, 3: 55.

2. A Kalir, HH Kalir (1993) In the Chemistry of Sulfur-Containing Functional Groups, supplements. Patai S, Z Rappoport, Wiley, New York, USA, pp. 957.

3. MC Carreno (1995) Applications of Sulfoxides to Asymmetric Synthesis of Biologically Active Compounds Chem Rev 95(6): 1717-1760.

4. I Fernandez, N Khiar (2003) Recent Developments in the Synthesis and Utilization of Chiral Sulfoxides Chem Rev 103(9): 3651-3705.

5. SR Dubbaka, P Vogel (2005) Palladium-Catalyzed Suzuki-Miyaura Cross- Couplings of Sulfonyl Chlorides and Boronic Acids. Angew Chem 117: 7848-7859.

6. Zefirov NS, Zyk NV, Beloglazkina EK, Kutateladze AG (1993) Sulfur Rep 14: 223

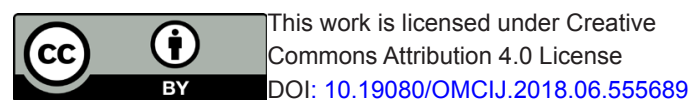

7. Trost BM (1978) alpha-Sulfenylated carbonyl compounds in organic synthesis. Chem Rev 78(4): 363-382.

8. Palumbo G, Ferreri C, D Ambrosio C, Caputo R (1984) Phosphorus Sulfur 19: 235.

9. Bosscher JK, Kraak EWA, Klooaterziel HJ (1971) Chem SOC D 21: 1365.

10. Dunbar JE, Harris RF, Mc Carthy JR (1972) Chem Abstr 82: 72796.

11. Smith DJ, Maggio ET, Kenyon GL (1975) Biochemistry 14: 766-771.

12. Applegate HE, Cimarusti CM, Dolfini JE, Funke PT, Koster WH, Puar MS, et al. (1979) Synthesis of 2-, 4-, and 7-methylthio-substituted cephalosporins. Org Chem 44(4): 811-818.

13. Slusarchyk WA, Applegate HE, Funke P, Koster W, Puar MS (1973) Org Chem 38: 943-950.

14. Ito Yoshiaki, Nakamura Yasushi, Nakamura Yoshiyuki (1997) Suppression of aflatoxin B1- or methyl methanesulfonate-induced chromosome aberrations in rat bone marrow cells after treatment with S-methyl methanethiosulfonate. Mutation Research 393(3): 307-316.

15. Nakamura Yasushi K, Kawai Kazuaki, Furukawa Hideyuki, Matsuo Tomoaki, Shimoi Kayoko (1997) Mutation Research 385(1): 41-46.

16. Freeman F, Bartosik LG, van Bui N, Keindl MC, Nelson EL (1988) Phosphorus Sulfur 35: 375.

17. Freeman F (1984) Chem Rev 84: 117.

18. Freeman F, Keindl MC (1983) Synthesis pp. 913.

19. Palumbo G, Caputo R (1981) Synthesis pp. 888.

20. Tsuchiya T, Iriyama S, Umezawa S (1963) Jpn Chem Soc Bull 37: 286.

21. Meier H, Menzel I (1972) Synthesis pp. 267.

22. Chemla F (1998) Synlett pp. 894.

23. Chemla F, Karoyan P (2004) Organic Syntheses Coll 546(78): 99.

24. Laszlo P, Mathy AJ (1984) Org Chem 49: 2281.

25. Griffiths IW, Howe I, March RE, Beynon JH (1983) Int J Mass Spectrom Ion Processes 54: 323.

\section{Your next submission with Juniper Publishers} will reach you the below assets

- Quality Editorial service

- Swift Peer Review

- Reprints availability

- E-prints Service

- Manuscript Podcast for convenient understanding

- Global attainment for your research

- Manuscript accessibility in different formats

( Pdf, E-pub, Full Text, Audio)

- Unceasing customer service

Track the below URL for one-step submission https://juniperpublishers.com/online-submission.php 